\title{
Nutritional reduction of protein and usage of enzyme in the diet of light layers
}

\section{Matheus Ramalho de Lima ${ }^{1 *}$, Fernando Guilherme Perazzo Costa ${ }^{2}$, Cláudia de Castro Goulart ${ }^{2}$, Sarah Gomes Pinheiro², Rafael Barbosa de Souza², Sérgio Antonio de Normando Morais², Raffaella Castro Lima ${ }^{2}$}

\author{
${ }^{1}$ Pós-graduação em Zootecnia, CCA/UFPB, Areia, PB, Brazil. \\ ${ }^{2}$ Departamento de Zootecnia, CCA/UFPB, Areia, PB, Brazil.
}

\begin{abstract}
The objective of this study was to evaluate the reduction of protein, the formulation of diets and supplementation of an enzyme complex for laying hens. The layers were distributed in a completely randomized $2 \times 2 \times 2$ factorial arrangement, with two levels of crude protein reduction $(0.0$ and $4.0 \mathrm{~g} / \mathrm{kg})$, two kinds of diet formulation (without and with reformulation, considering $75 \mathrm{kcal}$ of metabolizable energy) and two enzyme supplementations (without and with enzyme complex supplementation), totalizing 8 treatments of 8 layers each, with 7 replications, in a total of 448 laying hens at 30 weeks of age. After data analysis, it was found that the enzyme complex supplementation in the diet of layers improves performance, promotes a similar egg quality and improves the bone and intestinal health of the layers.
\end{abstract}

Key Words: bone health, egg quality, intestinal health, performance

\section{Introduction}

Enzymes are added to animal feed in order to increase digestibility ( $\mathrm{Li}$ et al., 2010), to remove antinutritional factors, and to improve nutrient availability, as well as for environmental reasons, and can be an improvement to intestinal health in relation to bacterial contamination (Peek, 2009). A large variety of carbohydrases, proteases, phytases and lipases are used for these purposes.

According to Soto-Salanova (1996), feed enzymes act by causing the rupture of cell walls of fibers, reducing digesta viscosity in the intestine, which can cause a reduction of proteins and the effects of anti-nutritional factors, increasing nutrient digestibility and supplementing the production of endogenous enzymes. Thus, the use of enzymes in the diet enables changes in the formulations of the diets in order to minimize cost and to maximize the use of energy and protein ingredients of diets.

Public opinion and campaigns to ban antibiotics in poultry production have prevailed in the restriction of antimicrobials in animal feed. Thus, various additives have been used in poultry diets as alternatives to antibiotics, among which are mannanoligosaccharides, fructooligosacharides, fumaric acid, dried mushroom and probiotics (Santos et al., 2002), as well as enzymes (Selle \& Ravindran, 2007) that promote reduction in the substrate available for microorganisms in the cecum of layers, improving their health status. These additives have provided favorable conditions for the development of beneficial microorganisms in the gastrointestinal tract, resulting in better digestion and absorption of nutrients, improving the quality of final products, without endangering the health of the consumer (Fuini, 2001; Santos et al., 2002).

The enzyme complex used in this research is composed of the following enzymes: phytase, protease, xylanase, betaglucanase, cellulase, amylase and pectinase. This enzyme complex is produced from the fungus Aspergillus niger, not genetically modified, which is capable of increasing the availability of energy, protein, amino acids, phosphorus and calcium.

The objective of this study was to evaluate the energy and protein release of enzyme complex in diets for layer hens and the effects of the enzyme on the microbial flora of the caeca of layers.

\section{Material and Methods}

The study was conducted in the research area with layers from CCA, Universidade Federal da Pabaíba (UFPB), Areia, Paraíba, Brazil. The experimental period was divided into five sub-periods of 28 days each. 
The layers were distributed in a completely randomized $2 \times 2 \times 2$ factorial design, with two added levels of crude protein (0 and $4.0 \mathrm{~g} / \mathrm{kg}$ ), two kinds of diet formulation (without and with reformulation, considering an increase of $75 \mathrm{kcal} \mathrm{ME}$ ) and two enzyme supplementations (without and with enzyme complex addition), totalizing 8 treatments of 8 layers each, with 7 replications, in a total of 448 laying hens at 30 weeks of age.

Treatment 1 (Table 1) was formulated according to recommendations of Rostagno et al. (2005). The negative control was formulated with $7 \%$ reduction in the levels of metabolizable energy, crude protein, digestible lysine, methionine + cystine and threonine. Treatments consisted of nutrient reduction and energy increase with the addition of the enzyme complex, so that the treatments were arranged as follows: treatment 1: $0.0 \mathrm{~g} / \mathrm{kg} \mathrm{CP}$ reduction (without reformulation and without enzyme complex); treatment 2 : $0.0 \mathrm{~g} / \mathrm{kg}$ CP reduction plus enzyme complex; treatment 3: $4.0 \mathrm{~g} / \mathrm{kg}$ CP reduction without reformulation and without enzyme complex; treatment $4=4.0 \mathrm{~g} / \mathrm{kg} \mathrm{CP}$ reduction without reformulation plus enzyme complex; treatment $5=$ $0.0 \mathrm{~g} / \mathrm{kg} \mathrm{CP}$ reduction plus reformulation of $75 \mathrm{kcal} / \mathrm{kg}$ and without enzyme complex; treatment $6=0 \mathrm{~g} / \mathrm{kg}$ CP reduction plus reformulation of $75 \mathrm{kcal} / \mathrm{kg}$ plus enzyme complex; treatment $7=4.0 \mathrm{~g} / \mathrm{kg} \mathrm{CP}$ reduction plus reformulation of $75 \mathrm{kcal} / \mathrm{kg}$ and without enzyme complex; and treatment $8=$ $4.0 \mathrm{~g} / \mathrm{kg}$ CP reduction plus reformulation of $75 \mathrm{kcal} / \mathrm{kg}$ plus enzyme complex.

The layers were housed in cages of $24 \times 37 \times 41 \mathrm{~cm}$ and received 17 hours of light (natural and artificial) with

Table 1 - Percentage composition of the experimental diets

\begin{tabular}{|c|c|c|c|c|c|c|c|c|}
\hline \multirow[b]{2}{*}{ Items, $\mathrm{g} / \mathrm{kg}$} & \multicolumn{8}{|c|}{ Diets } \\
\hline & $0.0 \mathrm{~g} / \mathrm{kg}$ & $\begin{array}{c}0.0 \mathrm{~g} / \mathrm{kg} \\
+ \text { enzyme } \\
\text { complex }\end{array}$ & $\begin{array}{c}4.0 \mathrm{~g} / \mathrm{kg} \\
+ \text { enzyme } \\
\text { complex }\end{array}$ & $\begin{array}{l}\quad 0 \% \\
\text { reduction }+ \\
\text { reformulation } \\
+ \text { enzyme } \\
\text { complex }\end{array}$ & $\begin{array}{l}0 \%+ \\
\text { reformulation }\end{array}$ & $\begin{array}{l}0 \mathrm{~g} / \mathrm{kg}+ \\
\text { reformulation } \\
+ \text { enzyme } \\
\text { complex }\end{array}$ & $\begin{array}{l}4.0 \mathrm{~g} / \mathrm{kg}+ \\
\text { reformulation }\end{array}$ & $\begin{array}{l}4.0 \mathrm{~g} / \mathrm{kg}+ \\
\text { reformulation } \\
+ \text { enzyme } \\
\text { complex }\end{array}$ \\
\hline Corn & 622.8 & 622.8 & 636.6 & 641.1 & 641.1 & 596.7 & 655.9 & 621.8 \\
\hline Soybean meal & 234.9 & 234.9 & 223.4 & 223.4 & 231.3 & 220.3 & 218.9 & 209.7 \\
\hline Limestone & 85.01 & 85.01 & 85.05 & 80.50 & 85.05 & 8.6 .14 & 85.10 & 86.15 \\
\hline Soybean oil & 21.72 & 21.72 & 19.38 & 19.38 & 6.98 & 27.21 & 4.46 & 20.26 \\
\hline Meat and bone meal & 20.00 & 20.00 & 2.00 & 2.00 & 20.00 & 20.00 & 20.00 & 20.00 \\
\hline Wheat meal & 0.00 & 0.00 & 0.00 & 0.00 & 0.00 & 40.00 & 0.00 & 32.41 \\
\hline Dicalcium phosphate & 7.49 & 7.49 & 7.55 & 7.55 & 7.45 & 1.72 & 7.51 & 1.84 \\
\hline Salt & 4.16 & 4.16 & 4.17 & 4.17 & 4.16 & 4.17 & 4.17 & 4.18 \\
\hline DL-methionine & 2.12 & 2.12 & 2.02 & 2.02 & 2.10 & 2.01 & 2.01 & 1.90 \\
\hline L-lysine HCL & 0.08 & 0.08 & 0.17 & 0.17 & 0.15 & 0.00 & 0.27 & 0.08 \\
\hline Choline chloride & 0.70 & 0.70 & 0.70 & 0.70 & 0.70 & 0.70 & 0.70 & 0.70 \\
\hline Mineral premix ${ }^{1}$ & 0.50 & 0.50 & 0.50 & 0.50 & 0.50 & 0.50 & 0.50 & 0.50 \\
\hline Vitamin premix ${ }^{2}$ & 0.25 & 0.25 & 0.25 & 0.25 & 0.25 & 0.25 & 0.25 & 0.25 \\
\hline Enzyme complex ${ }^{3}$ & 0.00 & 0.15 & 0.00 & 0.15 & 0.00 & 0.15 & 0.00 & 0.15 \\
\hline Antioxidant ${ }^{4}$ & 0.01 & 0.01 & 0.01 & 0.01 & 0.01 & 0.01 & 0.01 & 0.01 \\
\hline Inert $^{5}$ & 0.15 & 0.00 & 0.15 & 0.00 & 0.15 & 0.00 & 0.15 & 0.00 \\
\hline Total & 1000.0 & 1000.0 & 1000.0 & 1000.0 & 1000.0 & 1000.0 & 1000.0 & 1000.0 \\
\hline \multicolumn{9}{|l|}{ Nutritional composition } \\
\hline Metabolizable energy, $\mathrm{kcal} / \mathrm{kg}$ & 2.900 & 2.900 & 2.900 & 2.900 & 2.825 & 2.900 & 2.825 & 2.900 \\
\hline Crude protein, $\mathrm{g} / \mathrm{kg}$ & 170.0 & 170.0 & 166.0 & 166.0 & 170.0 & 170.0 & 166.0 & 166.0 \\
\hline Calcium, g/kg & 3.83 & 3.83 & 3.83 & 3.83 & 3.83 & 3.83 & 3.83 & 3.83 \\
\hline Potassium, g/kg & 6.33 & 6.33 & 6.16 & 6.16 & 6.32 & 6.38 & 6.38 & 6.14 \\
\hline Sodium, g/kg & 2.14 & 2.14 & 2.14 & 2.14 & 2.14 & 2.14 & 2.14 & 2.14 \\
\hline Chlorine, $\mathrm{g} / \mathrm{kg}$ & 2.94 & 2.94 & 2.95 & 2.95 & 2.94 & 2.95 & 2.95 & 2.96 \\
\hline Available phosphorus, $\mathrm{g} / \mathrm{kg}$ & 3.57 & 3.57 & 3.57 & 3.57 & 3.57 & 3.57 & 3.57 & 3.57 \\
\hline Digestible methionine + cystine, $\mathrm{g} / \mathrm{kg}$ & 6.90 & 6.90 & 6.73 & 6.73 & 6.90 & 6.90 & 6.73 & 6.73 \\
\hline Digestible lysine, $\mathrm{g} / \mathrm{kg}$ & 7.58 & 7.58 & 7.39 & 7.39 & 7.58 & 7.58 & 7.39 & 7.39 \\
\hline Digestible arginine, $\mathrm{g} / \mathrm{kg}$ & 10.17 & 10.17 & 9.86 & 9.86 & 10.12 & 10.30 & 9.93 & 9.93 \\
\hline Digestible threonine, $\mathrm{g} / \mathrm{kg}$ & 5.57 & 5.57 & 5.43 & 5.43 & 5.57 & 5.57 & 5.43 & 5.43 \\
\hline Digestible trypthonan, $\mathrm{g} / \mathrm{kg}$ & 1.74 & 1.74 & 1.70 & 1.70 & 1.73 & 1.75 & 1.68 & 1.68 \\
\hline
\end{tabular}

${ }^{1}$ Content/kg of product: vit. A - 12,000,000 IU; vit. D3 - 3,600,000 IU; vit. B1 - 2.5 g; vit. B2 - 8 g; vit. B6 - 3 g; panthotenic acid - 12 g; biotin - 0.2 g; vit. K - 3 g; folic acid - 3.5 g; nicotinic acid - $40 \mathrm{~g}$; vit. B12 - $20 \mathrm{mg}$; Se - $0.13 \mathrm{~g}$; excipient q.s. - 1,000 g.

${ }^{2}$ Content/kg of product: $\mathrm{Mn}-160 \mathrm{~g}$; Fe $-100 \mathrm{~g} ; \mathrm{Zn}-100 \mathrm{~g} ; \mathrm{Cu}-20 \mathrm{~g}$; Co - 2 g; I - 2 g; excipient q.s. - 1,000 g.

${ }^{3}$ Allzyme SSF (cellulase, pentosanase, pectinase, amylase, protease, $\beta$-glucanase, phytase).

${ }^{4}$ Butylated hydroxytoluene.

${ }^{5}$ Washed sand.

${ }^{6}$ Rostagno et al. (2005). 
digital control. Feed and water were supplied ad libitum. Egg production was verified 20 days before the beginning of the experimental period in order to assess and maintain the homogeneity of experimental units.

The parameters evaluated at the end of each period were: feed intake, egg production, egg weight, egg mass, conversion per mass and per dozen eggs, percentages of albumen, shell, yolk, and total solids of yolk and albumen. At the end of the test, two layers were slaughtered per plot, and blood samples were taken for the analysis of the levels of calcium, phosphorus and total proteins, and their tibias were evaluated for the content of calcium, phosphorus and magnesium.

The weight and length of the large and small intestines and the weight of the pancreas were measured. The cecum was separated in plastic bags for analysis of total bacterial count. From each cecum, aliquots of cecum contents were collected, homogenized and weighed. Later, $1 \mathrm{~g}$ of the aliquot was collected and placed in a Falcon tube, $9 \mathrm{~mL}$ of saline solution was added, and it was again homogenized (dilution 1:10). Three repetitions were performed from each tube, with five dilutions each, inoculated in Mac Conkey agar at levels of $10^{-3}, 10^{-4}$ and $10^{-5}$. The count of colonies was made by using the surface plate technique (Branson, 1972).

The left tibia was used for the resistance analysis and the right tibia was used to determine the content of ash, calcium, phosphorous and magnesium in the bones, after fat extraction, drying at $55^{\circ} \mathrm{C}$ and $100{ }^{\circ} \mathrm{C}$ for 18 and 2 hours, respectively, and incineration at $600{ }^{\circ} \mathrm{C}$ for 16 hours. The analyses of the blood and tibias of the layers were performed in the Laboratório de Qualidade de Alimentos of Universidade Federal da Paraiba, in the city of Bananeiras, state of Paraiba, Brazil. The microbiological analyses had already been carried out in the Laboratório de Análise de Alimentos de Origem Animal of Universidade Federal da Paraiba, in the city of Areia, state of Paraiba, Brazil.

Data were submitted to analysis of variance and Tukey test to compare means two by two, with utilization of the statistical program SAS (Statistical Analysis System, version 8.0 ). For the analysis, $\alpha=0.05$ and 0.01 .

\section{Results}

Concerning the productive performance of laying hens, only production and the weight of the eggs were influenced $(\mathrm{P}<0.05)$ by the diet formulation (Table 2$)$.

The reformulation of the diet improved the egg production in relation to the normal diet. However, this behavior was not repeated in egg weight, which had an opposite result.

As for the internal and external quality of the eggs, no interaction was observed between the studied factors, corroborated by some scientific studies that treated similar evaluations (Table 3).

Table 2 - Feed intake and egg characteristics of laying hens, according to crude protein reduction, diet formulation and enzyme complex supplementation

\begin{tabular}{|c|c|c|c|c|c|c|c|}
\hline \multirow{2}{*}{ Variable } & \multicolumn{2}{|c|}{ Crude protein reduction } & \multicolumn{2}{|c|}{ Diet formulation } & \multicolumn{2}{|c|}{ Enzyme complex } & \multirow{2}{*}{ SEM } \\
\hline & $0.0 \mathrm{~g} / \mathrm{kg}$ & $4.0 \mathrm{~g} / \mathrm{kg}$ & Normal & Reformulated & Without & With & \\
\hline Feed intake (g/bird/day) & 114.8 & 115 & 115 & 114.8 & 114.8 & 115.0 & 0.255 \\
\hline Egg production (egg/day/bird) & 0.950 & 0.949 & $0.944 B$ & $0.955 \mathrm{~A}$ & 0.948 & 0.952 & 0.257 \\
\hline Egg weight (g) & 64.8 & 64.2 & $65.0 \mathrm{~A}$ & $64.0 \mathrm{~B}$ & 64.3 & 64.6 & 0.205 \\
\hline Egg mass (g/bird/day) & 61.0 & 61.5 & 61.3 & 61.2 & 64.3 & 64.6 & 0.246 \\
\hline Feed conversion per egg mass $(\mathrm{g} / \mathrm{g})$ & 1.885 & 1.874 & 1.881 & 1.879 & 1.886 & 1.874 & 0.008 \\
\hline Feed conversion per egg dozen ( $\mathrm{kg} /$ dozen $)$ & 1.451 & 1.456 & 1.464 & 1.443 & 1.455 & 1.452 & 0.005 \\
\hline
\end{tabular}

Means followed by different letters on the same row differ statistically by the Tukey test at $5 \%$ probability.

SEM - standard error of the mean.

Table 3 - Internal and external characteristics of the eggs, according with crude protein reduction, diet formulation and enzyme complex supplementation

\begin{tabular}{|c|c|c|c|c|c|c|c|}
\hline \multirow{2}{*}{ Variable } & \multicolumn{2}{|c|}{ Crude protein reduction } & \multicolumn{2}{|c|}{ Diet formulation } & \multicolumn{2}{|c|}{ Enzyme complex } & \multirow{2}{*}{ SEM } \\
\hline & $0.0 \mathrm{~g} / \mathrm{kg}$ & $4.0 \mathrm{~g} / \mathrm{kg}$ & Normal & Reformulated & Without & With & \\
\hline Specific gravity $\left(\mathrm{g} / \mathrm{cm}^{3}\right)$ & 1.0817 & 1.0832 & 1.0814 & 1.0835 & 1.0813 & 1.0837 & 0.0009 \\
\hline Haugh unit & 97.0 & 97.2 & 96.7 & 97.4 & 97.5 & 96.7 & 0.440 \\
\hline Albumen (mg/g egg) & 0.589 & 0.591 & 0.588 & 0.593 & 0.595 & 0.585 & 0.302 \\
\hline Shell (g/g egg) & 0.133 & 0.134 & 0.134 & 0.133 & 0.132 & 0.135 & 0.108 \\
\hline Yolk (mg/g egg) & 0.276 & 0.272 & 0.275 & 0.273 & 0.270 & 0.278 & 0.250 \\
\hline Albumen total solids (mg/g albumen) & 0.160 & 0.162 & 0.163 & 0.159 & 0.159 & 0.163 & 0.141 \\
\hline
\end{tabular}

SEM - standard error of the mean. 
The variables of internal and external quality of the eggs were not influenced by the factors evaluated, except for the total solids of the yolk, which had an interaction between protein reduction and diet formulations (Table 4).

The absence of significant effect is corroborated by results presented by Gentilini et al. (2009). This fact can be associated to the similar availability of nutrients in all of the diets, although there was reformulation and/or protein reduction. Coupled with these factors, it is possible that the addition of the enzyme complex increased the availability of the nutrients, making the quality of the eggs not statistically different among the treatments.

The content of the plasmatic calcium was influenced by the reduction of the crude protein $(\mathrm{P}<0.05)$. Enzyme supplementation promoted a reduction $(\mathrm{P}<0.05)$ of pancreas weight, going from 4.91A to 4.19B (Table 5).

One of the improvements that enzyme supplementation in the diet of layers provides is the reduction of the bacterial population present in the ceca of the layers (Choct, 2001). In the present study (Table 6), a significant interaction $(\mathrm{P}<0.05)$ between the formulation of the diets and the protein reduction was observed.

Protein reduction provided better results in relation to the bacterial count in the ceca $(\mathrm{P}<0.05)$, especially when the diet was not reformulated. When the diet did not have protein reduction $(0.0 \mathrm{~g} / \mathrm{kg})$, bacterial count was lower in the reformulated diet $(\mathrm{P}>0.05)$. The content of plasmatic phosphorus had a similar behavior in the layers whose diet had a protein reduction, causing a reduction of the content

Table 4 - Interaction between crude protein reduction and diet formulation for total yolk solids ( $\mathrm{mg} / \mathrm{g}$ of yolk)

\begin{tabular}{lccc}
\hline \multirow{2}{*}{$\begin{array}{l}\text { Crude protein } \\
\text { reduction }\end{array}$} & \multicolumn{2}{c}{ Diet formulation } & \multirow{2}{*}{ SEM } \\
\cline { 2 - 3 } & Normal & Reformulated & \\
\hline $0.0 \mathrm{~g} / \mathrm{kg}$ & $0.753 \mathrm{Aa}$ & $0.703 \mathrm{Bb}$ & \multirow{2}{*}{0.387} \\
$4.0 \mathrm{~g} / \mathrm{kg}$ & $0.693 \mathrm{Bb}$ & $0.731 \mathrm{Aa}$ & \\
\hline
\end{tabular}

Means followed by different uppercase and lowercase letters on the same row and column, respectively, differ by the Tukey test at $5 \%$ probability.

SEM - standard error of the mean. of this variable in the non-reformulated diets, and having a contrary effect on the reformulated diets $(\mathrm{P}<0.05)$.

As to intestine weight, there was an increase with protein reduction in the layers that received non-reformulated diets and a reduction in the layers fed reformulated diets. This can be explained by the greater need of reduction of the passage rates for the feed to be as much used as possible.

There was an interaction $(\mathrm{P}<0.05)$ as to the content of magnesium present in the tibias of the layers in relation to the enzyme supplementation in the diets and protein reduction (Table 7).

According to the data presented, protein reduction influenced $(\mathrm{P}<0.05)$ the content of magnesium in the tibias of the layers fed diets without enzymes, and the best result was observed in the diet without protein reduction. The diets with enzyme supplementation did not differ significantly $(\mathrm{P}>0.05)$ in relation to protein reduction.

Bacterial count was influenced by the formulation of the diet in relation to protein reduction, and magnesium presented a significant effect on the interaction between enzyme supplementation and protein reduction (Table 8).

The magnesium content present in the tibias of the layers was influenced by the formulation of the diets $(\mathrm{P}<0.05)$, especially in the non-reformulated diets. Knowing that magnesium is an extremely important mineral in the animal metabolism, its reduction in non-reformulated diets supplemented with enzyme complex can produce a negative effect on bone quality, considering that magnesium deficiency can generate locomotor problems, besides the reduction in the production of eggs. However, in this study, this decrease was not sufficient to reduce bone quality.

A contrary effect of this variable occured in the reformulated diets, and although there was no significant effect, enzyme supplementation elevated the mineral content of the tibias of the layers in relation to the diets without the enzyme complex. So the utilization of the enzyme supplementation was not beneficial to elevate the content of magnesium when the layers received a diet

Table 5 - Plasmatic calcium and variables of the digestive tract and the mineral content of the tibias of the birds according with crude protein reduction, diet formulation and enzyme complex supplementation

\begin{tabular}{|c|c|c|c|c|c|c|c|}
\hline \multirow{2}{*}{ Variable } & \multicolumn{2}{|c|}{ Crude protein reduction } & \multicolumn{2}{|c|}{ Diet formulation } & \multicolumn{2}{|c|}{ Enzyme complex } & \multirow{2}{*}{ SEM } \\
\hline & $0.0 \mathrm{~g} / \mathrm{kg}$ & $4.0 \mathrm{~g} / \mathrm{kg}$ & Normal & Reformulated & Without & With & \\
\hline Plasmatic calcium (mg/dL) & $3.00 \mathrm{~A}$ & $2.74 \mathrm{~B}$ & 2.91 & 2.82 & 2.77 & 2.96 & 0.050 \\
\hline Small intestine length $(\mathrm{cm})$ & 148.1 & 146.3 & 147.9 & 146.5 & 145.9 & 148.4 & 1.561 \\
\hline Pancreas weight (g) & 4.55 & 4.55 & 4.59 & 4.51 & $4.91 \mathrm{~A}$ & 4.19B & 0.059 \\
\hline Phosphorus content in the tibia & 6.47 & 6.42 & 6.55 & 6.34 & 6.27 & 6.62 & 0.157 \\
\hline Calcium in the tibia $(\mathrm{mg} / \mathrm{g})$ & 12.04 & 12.43 & 12.36 & 12.11 & 12.21 & 12.27 & 0.176 \\
\hline
\end{tabular}

Means followed by different letters on the same row differ by the Tukey test at $5 \%$ probability.

SEM - standard error of the mean. 
Table 6 - Interaction between crude protein reduction and diet formulation for total bacterial count in the cecum and plasmatic phosphorus and small intestine weight of hens

\begin{tabular}{|c|c|c|c|}
\hline \multirow{2}{*}{$\begin{array}{l}\text { Crude protein } \\
\text { reduction }\end{array}$} & \multicolumn{2}{|c|}{ Diet formulation } & \multirow{2}{*}{ SEM } \\
\hline & Normal & Reformulated & \\
\hline \multicolumn{4}{|c|}{ Bacterial count in the cecum $\left(\mathrm{fcu} 10^{-5} / \mathrm{mL}\right.$ ) } \\
\hline $\begin{array}{l}0.0 \mathrm{~g} / \mathrm{kg} \\
4.0 \mathrm{~g} / \mathrm{kg}\end{array}$ & $\begin{array}{l}5.96 \mathrm{Aa} \\
4.55 \mathrm{Bb}\end{array}$ & $\begin{array}{l}4.96 \mathrm{~B} \\
5.00 \mathrm{~A}\end{array}$ & 0.103 \\
\hline \multicolumn{4}{|c|}{ Plasmatic phosphorus (mg/dL) } \\
\hline $\begin{array}{l}0.0 \mathrm{~g} / \mathrm{kg} \\
4.0 \mathrm{~g} / \mathrm{kg}\end{array}$ & $\begin{array}{l}1.68 \mathrm{Aa} \\
1.20 \mathrm{Bb}\end{array}$ & $\begin{array}{l}1.41 \mathrm{~B} \\
1.56 \mathrm{~A}\end{array}$ & 0.037 \\
\hline \multicolumn{4}{|c|}{ Small intestine weight $(\mathrm{g})$} \\
\hline $\begin{array}{l}0.0 \mathrm{~g} / \mathrm{kg} \\
4.0 \mathrm{~g} / \mathrm{kg}\end{array}$ & $\begin{array}{c}68.2 \\
73.4 \mathrm{~A}\end{array}$ & $\begin{array}{c}71.6 \mathrm{a} \\
57.4 \mathrm{Bb}\end{array}$ & 1.701 \\
\hline
\end{tabular}

Table 7 - Interaction between crude protein reduction and enzyme complex supplementation of magnesium present in the tibia of hens

\begin{tabular}{|c|c|c|c|}
\hline \multirow{2}{*}{$\begin{array}{l}\text { Crude protein } \\
\text { reduction }\end{array}$} & \multicolumn{2}{|c|}{ Enzyme complex } & \multirow{2}{*}{ SEM } \\
\hline & Without & With & \\
\hline \multicolumn{4}{|c|}{ Magnesium (mg/g) } \\
\hline $0.0 \mathrm{~g} / \mathrm{kg}$ & $0.640 \mathrm{Aa}$ & $0.533 \mathrm{~B}$ & \multirow{2}{*}{0.012} \\
\hline $4.0 \mathrm{~g} / \mathrm{kg}$ & $0.530 \mathrm{Bb}$ & $0.565 \mathrm{~A}$ & \\
\hline
\end{tabular}

Means followed by different uppercase and lowercase letters on the same row and column, respectively, differ by the Tukey test at $5 \%$ probability.

SEM - standard error of the mean.

Table 8 - Interaction between diet formulation and enzyme complex supplementation of magnesium present in the tibia of hens and total bacterial count in the cecae

\begin{tabular}{|c|c|c|c|}
\hline \multirow{2}{*}{ Diet formulation } & \multicolumn{2}{|c|}{ Enzyme complex } & \multirow{2}{*}{ SEM } \\
\hline & Without & With & \\
\hline \multicolumn{4}{|c|}{ Magnesium (mg/g) } \\
\hline $\begin{array}{l}\text { Normal } \\
\text { Reformulated }\end{array}$ & $\begin{array}{c}0.651 \mathrm{Aa} \\
0.519 \mathrm{~b}\end{array}$ & $\begin{array}{c}0.572 \mathrm{~B} \\
0.526\end{array}$ & 0.012 \\
\hline \multicolumn{4}{|c|}{ Bacterial count $(10-5 \mathrm{fcu} / \mathrm{mL})$} \\
\hline $\begin{array}{l}\text { Normal } \\
\text { Reformulated }\end{array}$ & $\begin{array}{l}5.81 \mathrm{Aa} \\
4.99 \mathrm{~b}\end{array}$ & $\begin{array}{c}4.70 \mathrm{~B} \\
4.97\end{array}$ & 0.103 \\
\hline
\end{tabular}

Means followed by different uppercase and lowercase letters on the same row and column, respectively, differ by the Tukey test at $5 \%$ probability.

SEM - standard error of the mean. without reformulation; however, in reformulated diets, the practice of using enzyme supplementation promoted better results with respect to the content of magnesium in the tibias of the layers.

The enzyme supplementation promoted an improvement in the content of plasma protein $(\mathrm{P}<0.05)$ in the layers that received the diet without protein increase and when these diets were reformulated (8.00B version 9.45A) (Table 9).

The enzymes improved $(\mathrm{P}<0.05)$ this variable when the non-formulated diet was replaced by the formulated one, reaching values of $8.00 \mathrm{Y}$ and $9.45 \mathrm{X}$, respectively. Aside from this, when the diet was reformulated and contained the enzyme supplement, the protein reduction diminished $(\mathrm{P}<0.05)$ the content of plasma protein in the layers, from $9.45 \mathrm{a}$ to $8.39 \mathrm{~b}$.

\section{Discussion}

Gentilini et al. (2009), evaluating the inclusion of an enzyme complex in the diet of layer chickens, observed that the consumption of feed and the weight of the eggs reduced when the diets contained enzyme complex and were reformulated. The results presented by these authors were not confirmed in this experiment in relation to feed intake, which was not significant $(\mathrm{P}>0.05)$. However, they corroborate the results in relation to the weight of the eggs, especially in relation to the reformulation of the diets, which made the layers produce lighter eggs. This behavior can be explained by the fact that layer chickens divert a greater energy load to the production of eggs in detriment of the weight of the egg.

Thus, the increase in the production of eggs observed in the reformulated diet in this study possibly occurred due to greater energy availability in the feed. However, the production was characterized by eggs of lower weights, since the consumption of feed was not altered according to the formulation of the diets, and this did not make enough nutrients available to the layers for the synthesis of the components of the eggs.

Table 9 - Interaction between crude protein reduction, diet formulation and enzyme supplementation of total plasma protein

\begin{tabular}{|c|c|c|c|c|c|}
\hline \multirow[t]{3}{*}{ Crude protein reduction } & \multicolumn{2}{|c|}{ Normal diet } & \multicolumn{2}{|c|}{ Reformulated diet } & \multirow{3}{*}{ SEM } \\
\hline & \multicolumn{2}{|c|}{ Enzyme complex } & \multicolumn{2}{|c|}{ Enzyme complex } & \\
\hline & Without & With & Without & With & \\
\hline $4.0 \mathrm{~g} / \mathrm{kg}$ & 8.1 & 8.17 & 8.17 & $8.39 b$ & $0.0 / 6$ \\
\hline
\end{tabular}

Means followed by different uppercase and lowercase letters on the same row and column, respectively, differ by the Tukey test at $5 \%$ probability. SEM - standard error of the mean. 
The data obtained in this research are similar to those found in national and international literature, especially in relation to the best usage of exogenous enzymes. Bedford (2002) states that the use of enzymes in diets that meet the daily requirements of layers causes the enzymes to not act efficiently, and not demonstrate their performance effect and benefit potential to animal nutrition. Thus, this effect shows that it is much better to use enzyme complexes in diets with the reduction of nutrients, than in complete diets. Garcia et al. (2009) comment that enzyme supplementation increases the retention of nitrogen, the use of metabolizable energy at all ages, and that these effects are more pronounced when the diets are formulated based on corn and soybean meal.

Another beneficial effect of enzyme performance in the nutrition of layers is stated by Rutherfurd et al. (2002), when indicating that the addition of phytase in the diet of layers enables a significant increase in the retention of minerals and improves the digestibility of aminoacids, lipids and carbohydrates. Choct (2001) verified that the dose of exogenous enzymes improved the digestibility of the dry matter by 0.17 , apparent metabolizable energy by 0.24 and conversion by 0.31 , and also reduced the viscosity of the digesta by $0.50 \mathrm{~g} / \mathrm{g}$. Thus, it can be affirmed that enzyme performance improves the performance and productivity of the poultry activity; however, this practice is more efficient and economically correct when using diets with some nutritional reduction, especially in the nutrients in which the enzyme acts efficiently.

In this study, protein reduction provoked a decrease in the total solid content of the yolks of the eggs from layers fed normal diets. However, when the diets were reformulated and the protein was reduced by $4.0 \mathrm{~g} / \mathrm{kg}$, the values were similar to those obtained by Gunawardana et al. (2009) when studying the effects on the performance of layer chickens during the second laying cycle fed different levels of energy, protein and enzymes; they did not obtain differences for the total solids present in the yolk. However, protein, when evaluated individually, presented a significant effect $(\mathrm{P}<0.05)$, and achieved better results when the bird received a diet with a lower protein level.

Kun Yuan \& Guangbing (2009) evaluated the effect of fat in the diet of Hy Line W-36 layer chickens during the first laying cycle, when fed different protein levels; these authors observed that the increase in fat from 0.0 to $4.0 \mathrm{~g} / \mathrm{kg}$ in the diet promoted a linear increase in the total solids of the egg, from 23.73 to $24.07 \%$. These authors concluded that the addition of fat in the diet of layer chickens can reduce the calorie increase, depending on the source of fat used, and consequently increase the availability of energy used to synthesize the total solids of the yolk.

Plasmatic calcium can confirm the effects on the metabolism of this mineral, because it goes through intense hormonal regulation, through calcitonin and PTH. It also directly influences the production of eggs because it participates in the formation of the egg shells in the form of calcium carbonate.

Although the diets had the same amount of calcium, lower levels of plasmatic calcium and greater deposition of the mineral in the tibia were observed when the layers were fed diets with reduced protein. This fact leads us to understand that protein reduction can promote a better proportional use of the ingested protein, enabling less energy expenditure with the excretion of possible excess of protein and elevating a greater supportability for bone mineral retention, since for this to be performed efficiently, there is a great energy expenditure by the animal. Thus, the practice of protein reduction improved calcium retention in the bones, which was proven by a lower content of this mineral in the bloodstream, and a higher content, although only numerically, in the tibias of the layers.

These results are corroborated by statements made by Bertechini et al. (1997), as to the importance of minerals in the nutrition of layers, when they described the concentrations in the bones. According to these authors, 98 to $99 \%$ of all the calcium contained in the organism of the layers is present in the bones, which makes the evaluation of the content of this mineral performed on the tibias a good variable to estimate mineral retention.

In a research study on the evaluation of enzyme activity and digestibility of nutrients, Sakomura et al. (2004) concluded that the maximal allometric growth of the pancreas coincided with the greatest increase in the production of the digestive endogenous enzymes, which, according to Viana et al. (2009), is induced by the addittion of enzyme complexes in the diet. In another experiment, conducted by Arija et al. (2006), the authors verified that the weights of the digestive organs, intestine and accessory organs and the intestinal viscosity were altered because of the inclusion of extruded beans in the diet of chicks in relation to those fed normal diets based on corn and soybean. According to these authors, the results of alteration in the organs happened due to the presence of antinutritional factors, such as the non-starch polysaccharides, present in the beans.

In relation to the pancreas, weight reduction was observed in this study when the diet contained the enzyme complex. This can be explained by the presence of the enzyme supplementation, which is possibly corroborated 
by the lowest pancreatic activity, promoting a reduction in the size and weight of the organ. Garcia et al. (2003), when evaluating the use of enzymes in the diet of layers in relation to the weight of the organs, observed that the weight of the pancreas had a significant reduction as the diet was supplemented with alpha-amylase.

In diets for non-ruminants, the enzyme activity should be high enough to permit the intestinal transit time to be relatively low. Furthermore, the enzyme used should be able to resist unfavorable conditions that naturally exist in the gastrointestinal tract or which may occur during the process of preparation of the feed, such as extrusion or pelleting (McCleary, 2001).

Zanella et al. (1999) commented that inclusion of exogenous enzymes reduces the endogenous production of amylase by $23.4 \%$ and pancreatic trypsin by $35.8 \%$, which could favor protein synthesis in the muscle tissue because of the greater availability of the aminoacids caused by this economy. Normally, commercial enzymes used as additives do not contain only one enzyme, but many, and are called enzyme complex. This is desirable, since feeds are composed of several ingredients (Campestrini et al., 2005; Viana et al., 2009).

The intestinal mucosa contains cells that have several functions that contribute to the digestion process and absorption, and work as barriers against pathogens (Smirnov et al., 2004). Since enzyme supplementation promotes a better distribution of the nutrients in the organism of the layer (Selle \& Ravidran, 2007), it enables a better structure for intestinal protection of the layers and a greater efficiency in this defense. To evaluate such effects, Peek (2009), working with protease supplementation in the diet of broilers, observed that supplementation improved the health of the animals, for the incidence of eimeriosis was reduced. This fact was corroborated by this study, because with supplementation of enzyme complex, the bacterial count was reduced (Table 8).

Onderci (2006), evaluating contamination by E. coli in the diet of broilers, verified that enzyme supplementation reduced the relative weight of the pancreas, but did not affect the weight of the liver, the length and weight of the duodenum, jejunum, ileum and cecae. However, the villus height and the crypt depth suffered a significant increase with bacterial contamination. In a study with layer chickens, Gentilini et al. (2009) verified that the inclusion of an enzyme complex in diets in an on top form yielded better results in relation to bacterial count, significantly reducing bacterial population in the cecae of the layers.
Another benefit provided by the addition of enzyme complex in feeds occurs because of the increase in the degradation of the feed due to a greater enzyme activity caused by these complexes. This greater enzyme activity tends to reduce the availability of substrate for the proliferation of microorganisms in the cecae of the layers, diminishing microorganism multiplication and consequently microorganism survival.

In this study, it could be verified that magnesium was influenced by the protein reduction in the diets, especially in the diets that did not have the addition of enzyme complexes. However, with the addition of enzymes, the influence on the protein reduction in the diet did not exist anymore, and thus, the mineral could be better incorporated in the tibias of the layers when they were fed diets containing enzyme complexes. Consequently, it could be observed that balanced nutrition is indispensable to maintain all biological processes, especially among the minerals present in the bones.

Magnesium, despite being indispensable to fixation of calcium in the bones (Mclean, 1994), is an antagonist when used in excess (Gilbert d'Angelo et al., 1992). Thus, its adequate fixation in the bones is associated to a good bone quality, a fact that can be influenced by the presence of exogenous enzymes, especially in diets with nutritional reduction, as demonstrated in this study.

The bacterial count was influenced $(\mathrm{P}<0.05)$ by the formulation of the diets. When it was not reformulated whether enzyme complex supplementation was used or not. However, the best results in relation to the lower bacterial population were observed in the layers fed a diet without reformulation and with the addition of the enzyme complex. Thus, it is possible to affirm that adding the enzyme complex reduced the availability of substrate to the microorganisms, and consequently, there was a drop of the bacterial load in the cecae of the layers (Selle \& Ravindran, 2007; Gonçalves, 2007). Ramesh \& Devegowda (2004) observed that the presence of enzyme complex reduced the undesirable cecal bacterial flora and they associated these results to the lower intestinal viscosity due to the greater digestibility influenced by the enzymes added to the diets.

The ability of food fermentation by the microbial microflora has an important effect on the provision of energy that is really utilized by the host, since the absorption of the products of the fermentation generate less energy for the organism than the products of enzyme digestion (Bedford, 1996a).

Studies show that the utilization of xylan-degrading enzymes inhibits fermentation in the ileum and stimulate 
fermentation in the ceca (Bedford, 2001; Persia, 2002). The reduction of fermentation in the ileum is beneficial for the host because most of the fermented material in this region is non-digested starch and protein, which will then remain available to be hydrolyzated and absorbed by the host (Bedford, 1996b). Furthermore, oligosaccharides resulting from the degradation of the non-starch polysaccharides by the exogenous enzymes would have a probiotic effect in the cecum, acting as substrate for the proliferation of beneficial bacterial for the host instead of pathogenic bacteria (Persia, 2002).

Hinton et al. (1993) reported that a greater production of lactic acid in the ileum and propionate in the cecae, with the utilization of xylanase in a diet based on wheat, favored intestinal health in broilers through competitive exclusion and the action of the propionate over salmonellas and other pathogenic bacteria. Murakami et al. (2007) state that the inclusion of enzyme complexes in bird feed can maximize the use of energy and protein ingredients of the feed. These authors affirm that the correct nutritional evaluation of the ingredients is fundamental, along with the economic viability of the use of this technology.

The plasma proteins, formed especially in the liver cells, can be degraded in aminoacids by the cells of the mononuclear phagocytic system and made availabile to form cell protein, especially when the supply of amino acids from the digestive processes is not sufficient to the animal (Reece, 2006).

The results herein presented validate the information given by Reece (2006), which show that when the diet receives enzyme supplement, the content of plasma proteins increases, demonstrating that this practice promotes an increase in the availability of aminoacids present in the feed.

\section{Conclusions}

The enzyme complex supplementation in the diet of white layers enables performance and egg quality similar to that without nutritional reduction and improvement in bone and intestinal health, reducing the bacterial load in the cecae and elevating the levels of calcium and phosphorous in the plasma of these layers.

\section{Acknowledgments}

The authors thank Alltech for the financial support, Jerônimo Galdino dos Santos for the laboratory analyses and Élcio Gonçalves dos Santos for the microbiological analyses.

\section{References}

ARIJA, I. Nutritional evaluation of raw and extruded kidney bean (Phaseolus vulgaris L. Pinto) in chickens diets. Poultry Science, v.85, p.635-644, 2006.

BEDFORD, M.R. The effect of enzymes on digestion. Journal of Applied Poultry Research, v.5, p.370-378, 1996a.

BEDFORD, M.R. Interaction between ingested feed and the digestive system in poultry. Journal of Applied Poultry Research, v.5, p.86-95, 1996b.

BEDFORD, M.R. Enzymes, antibiotics and intestinal microflora. Feed Mix, v.9, n.2, p.103-138, 2001.

BEDFORD, M.R. The foundation of conducting feed enzyme research and the challenge of explaining the results. Journal Applied Poultry Research, v.11, n.4, p.464-470, 2002.

BERTECHINI, A.G. Nutrição de monogástricos. Lavras: UFLA/ FAEPE, 1997. 273p.

BRANSON, D. Methods in clinical bacteriology: a manual of tests and procedures. Springfiels, Illinois: Charles C Thomas Publisher, 1972. p.126-127.

CAMPESTRINI, E. Utilização de enzimas na alimentação animal. Revista Eletrônica Nutritime, v.26, p.254-267, 2005.

CHOCT, M. Enzyme supplementation of poultry diets based on viscous cereals. In: BEDFORD, M.R.; PARTRIDGE, G.G. (Eds.) Enzymes in farm animal nutrition. Oxfordshire: Cab Publishing, 2001. 406p.

FUINI, M.G. Utilização do cogumelo Agaricus blazei como alternativa ao uso de antibióticos em rações para frangos de corte. 2001. 64f. Dissertação (Mestrado em Zootecnia) Universidade Federal de Lavras, Lavras.

GARCIA, M.I. $\alpha$-Amilase supplementation of broiler diets based on corn. Poultry Science, v.82, p.436-442, 2003.

GARCIA, M.I.; LÁZARO, R.; LATORRE, M.A. et al. Influence of enzyme supplementation of diets and cooking-flaking of maize on digestive traits and growth performance of broilers from 1 to 21 days of age. Animal Feed Science and Technology, v.150, p.303-315, 2009.

GENTILINI, F.P.; GONÇALVES, F.M.; NUNES, P.M. et al. Efeito de um complexo enzimático na production e na qualidade de eggs, nos níveis de proteins plasmáticas e na população bacteriana cecal em poedeiras semipesadas. Ciência Animal Brasileira, v.10, p.504-510, 2009a.

GILBERT D'ANGELO. Magnesium relaxes arterial smooth muscle by dcreasing intracellular $\mathrm{Ca}^{+2}$ without changing intracellular $\mathrm{Mg}^{+2}$. Journal Clinical Investigation, v.89, p.1988-1994, 1992.

GONÇALVES, F.M. Qualidade de ovos de poedeiras suplementadas com complex enzimático nas dietas. In: CONGRESSO DE INICIAÇÃO CIENTÍFICA, 16., 2007, Pelotas. Anais... Pelotas: UFPel/Faculdade de Agronomia Eliseu Maciel, 2007. p.34-39

GUNAWARDANA, P.; ROLAND, D.A.; BRYANT, M.M. Effect os diatary energy, protein, and a versatile enzima on hen performance, egg solids, egg composition, and egg quality of Hy-Line W-36 hens during second cycle, phase two. Journal Applied Poultry Research, v.18, p.43-53, 2009.

HINTON, A.; BUME, M.E.; DELOACH, J.R. Role of metabolic intermediates in the inhibition of Salmonella typhimurium and Salmonella enteritidis by Veillonella. Journal of Food Protection, v.56, p.932-937, 1993.

KUN YAN.; GUANGBING, WU. Effect of dietary fat and protein on performance, egg composition, egg solids, and egg quality of Hy-line W36 hens during Phase 1. Japan Poultry Science Association, v.46, p.322-327, 2009.

LI, Y.; FANG, Z.; DAI, J. Corn extrusion and enzyme addition improves digestibility of corn/soy based diets by pigs: In vitro and in vivo studies. Animal Feed Science and Technology, v.158, p.146-154, 2010.

MCCLEARY, B.V. Analysis of feed enzymes. In: BEDFORD, M.R.; PARTRIDGE, G.G. (Eds.) Enzymes in farm animal nutrition. County Wicklow, Irish Republic: CAB International, 2001. 406p. 
MCLEAN R.M. Magnesium and its therapeutic uses: a review. The American Journal of Medicine, v.96, p.63-79, 1994.

MURAKAMI, A.E. Efeito da suplementaçaõ enzimática no desempenho e qualidade dos ovos de poedeiras comerciais. Acta Scientarium Animal Science, v.29, p.165-172, 2007.

ONDERCI, M. Efficacy of supplementation of alfa-amilaseproducing bacterial culture on the performance, nutrient use, and gut morphology of broiler chickens fed a corn-based diet. Poultry Science, v.85, p.505-510, 2006.

PEEK, H.W. Dietary protease can alleviate negative effects of a coccidiosis infection on production performance in broiler chickens. Animal Feed Science and Technology, v.150, p.151-159, 2009.

PERSIA, M.E. The effects of enzyme supplementation of cornand wheat-based diets on nutrient digestion and cecal microbial populations in turkeys. Journal of Applied Poultry Research, v.11, p.134-145, 2002.

RAMESH, K.R. Effect of Allzyme ${ }^{\circledR}$ SSF supplementation on intestinal viscosity, bacterial load and performance in broiler chickens. In: Nutritional biotechnology in the feed and food industries. Alltech's 18th annual symposium, 20., 2004, Lexington. Proceedings... Lexington: Alltech, 2004.

REECE, W.O. Fisiologia dos animais domésticos. 12.ed. Rio de Janeiro: Editora Guanabara Koogan, 2006. 926p.

ROSTAGNO, H.S.; ALBINO, L.F.T.; DONZELE, J.L. et al. Brazilian tables for poultry and swine. Composition of feedstuffs and nutrition requirements. 2.ed. In: INTERNATIONAL SYMPOSIUM ON NUTRITIONAL REQUIREMENTS OF
POULTRY AND SWINE, 2., 2005, Viçosa, MG. Proceedings... Viçosa, MG, 2005. 186p.

RUTHERFURD, S.M.; CHUNG, T.K.; MOUGHAN, P.J. et al. The effect of microbial phytase on ileal phosphorus and amino acid digestibility in the broiler chicken. British Poultry Science, v.44, p.598-606, 2002.

SAKOMURA, N.K. Efeito da idade de frangos de corte sobre a atividade enzimática e digestibilidade dos nutrientes do farelo de soja e da soja integral. Revista Brasileira de Zootecnia, v.33 p.924-935, 2004.

SANTOS, E.C. et al. Efeitos dos aditivos beneficiadores de crescimento sobre bactérias totais, $\mathrm{pH}$ intestinal e $\mathrm{pH}$ das rações de frangos de corte. In: REUNIÃO ANUAL DA SOCIEDADE BRASILEIRA DE ZOOTECNIA, 39., 2002, Recife. Anais... Recife: SBZ, 2002 (CD-ROM).

SELLE, P.H.; RAVIDRAN, V. Microbial phytase in poultry nutrition: Review. Animal Feed Science and Technology, v.135, p.1-41, 2007.

SMIRNOV, A. Mucin dynamics in the chick small intestine are altered by starvation. Journal Nutrition, v.134, p.736-742, 2004.

SOTO-SALANOVA, M.F. Uso de enzimas em dietas de milho e soja para frangos de corte. In: CONFERÊNCIA APINCO DE CIÊNCIA E TECNOLOGIA AVÍCOLA, 1996, Campinas. Anais... Campinas: FACTA, 1996. p.71-76.

VIANA, M.T.S. Efeito do uso de enzimas sobre o desempenho e metabolismo de poedeiras. Revista Brasileira de Zootecnia, v.38 p.1068-1073, 2009.

ZANELLA, I. Effect of supplementation of broiler diets based on corn and soybeans. Poultry Science, v.78, p.561-568, 1999. 